\title{
Ilse Lehiste (January 31, 1922-December 25, 2010) In memoriam
}

(2012)

\author{
Juta Kitching \\ Vancouver, BC \\ kitchingjuta@gmail.com
}

Ilse Lehiste is remembered foremost as a distinguished scholar, the author of twenty books and some 300 articles and reviews, the internationally recognized professor, department chairperson and president of professional societies. She is honored by colleagues far and wide. Her contributions to linguistics remain a legacy forever.

FUSAC members also know her as a remarkable human being, supportive and strong in a graceful way, always available for consultation, always presenting papers at conferences.

I met professor Lehiste when I was a graduate student in the 1960's at Indiana University in Bloomington. She was introduced to me as a linguist from Ohio State University, with a Ph.D. from Hamburg (1948) and a second Ph.D. from Ann Arbor (1959). Later on numerous honorary Ph.D.'s followed. Her university studies started in 1942 at Tartu, to be interrupted in 1944 with an escape to Germany. Hers was a familiar destiny, and I related to both her refugee status and to her intellectual pursuits. The paper she presented at IU dealt with quantity in Estonian and inspired me to study her works, particularly on quantity, palatalization and grammatical structures. Still later she invited me to investigate with her the changes in Estonian as spoken in our English language environment. Language contact and the resulting change were very real.

In the 1960's Ilse Lehiste's research led her to other scholars of Estonian background living in the West (Alo Raun, Felix Oinas, Ants Oras, Viktor Kõressaar, Aleksis Rannit, Julius Mägiste, and Valter Tauli). Interactions with linguists from Estonia began 1965 in Helsinki at the Second International Congress of Finno-Ugric Studies, the international conference in which Ilse continued to participate every five years. Direct contact with Estonia was difficult in the early years, but, even then, she was able to exert influence -- for example, in the development of experimental phonetics. In 1987 Dr. Lehiste organized the World Congress of Phoneticians in Tallinn, and there close contacts with many Estonian colleagues began, notably the linguist Karl Pajusalu and the musician Jaan Ross. Productive years of collaboration began: books were published, lectures given, students supported. Ilse's work has already given rise to a new generation of phoneticians at Tartu University. 
Ilse Lehiste was a remarkable and gifted human being. In addition to her intellect, she was also creative and artistic. Did you know about her volume of poetry in Estonian entitled "Songs Written in my Youth; Poems from 1938-1948 [Noorest peast kirjutatud laulud: luuletusi aastaist 1938-1948] (Scarborough: Maarjamaa, 1989)? Literature was a great pastime, and in her groups and book clubs she led discussions and took pleasure in also introducing Estonian literature. Ilse was a translator of literature herself and wrote regular reviews of new Estonian publications in World Literature Today. Folk-poetry and runic songs intrigued her. She was also an able musician, having studied piano in Estonia and having earned her first livelihood in the US as the pianist for a ballet school.

Professor Lehiste remained professionally active into December 2010, the last month of her life. In August of that year she even spent time with colleagues in both Estonia and at the Finno-Ugric Congress in Piliscsaba, Hungary where she gave the plenary address and presented some results of her and Karl Pajusalu's Finno-Ugric prosody project ('Experimental study of prosody in Finno-Ugric languages', by Ilse Lehiste ja Karl Pajusalu, published in Congressus XI Internationalis Fenno-Ugristarum, Piliscsaba 2010 part 1, pp. 225-245). However, her correspondence in the last year reveals a winding down and serene acceptance of age and change.

Jaan Ross, colleague and co-author of Temporal Structure of the Estonian Runic Songs (Mouton de Gruyter, 2001, 205 pp.), has published ten letters by Ilse to him, all written in 2010. These reveal cultural thoughts and personal feelings in the last months of her life. Her tone throughout is informal and warm, even humourous and self-effacing. She admits that old age descended suddenly -- it was in 2006, and she could even check the date. On the one hand, she makes tonguein-cheek comments about being a linguistic snob at times because wrong use of language irks her; on the other hand, she is sentimental and longs for the spring flowers of Estonia and reviews memories of her childhood and youth. Also very observant of her present surroundings, she cannot help but note a disconnectedness to the modernization at her Ohio State University, even to the linguistics laboratory. Ilse is also forthcoming with information of her health: she writes about two accidents, one at home in May and the other one in the car in November. She blames herself, is happy that no one else was hurt, but seems to need considerable recovery time herself. In her letter of November 19, 2010 to Ross she feels a cold coming on with shivers and a dripping nose... and delights in the fact that she cannot pass it on through e-mail. She then goes to lie down for a while.

Jaan Ross refers to Ilse as the bridge between the linguists and philologists of Estonia and the West. The laurels bestowed upon Professor Lehiste by Estonia in later years include the Estonian Order of the White Star in 2001, nomination by the Estonian Academy of Sciences as a Foreign Member 2008, and Laureate of the Wiedemann Language Prize in 2009. 
We in FUSAC knew Ilse as a great friend, supporter and promoter of our academic organization and pursuits. We will remember her grace, greatness and warm friendship. We thank Ilse Lehiste with all our hearts! 